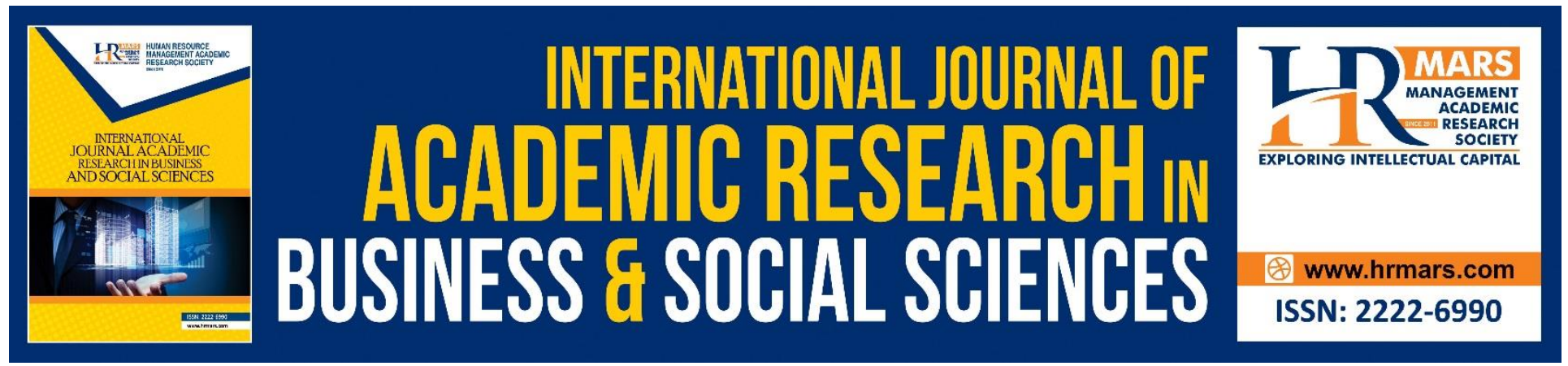

\title{
Financial Development and Environmental Degradation in ASEAN-5
}

\section{Rosita Hamdan, Rossazana Ab-Rahim \& Sang Sook Fah}

To Link this Article: http://dx.doi.org/10.6007/IJARBSS/v8-i12/4987

DOI: $10.6007 /$ IJARBSS/v8-i12/4987

Received: 07 Nov 2018, Revised: 01 Dec 2018, Accepted: 15 Dec 2018

Published Online: 16 Dec 2018

In-Text Citation: (Hamdan, Ab-Rahim, \& Fah, 2018)

To Cite this Article: Hamdan, R., Ab-Rahim, R., \& Fah, S. S. (2018). Financial Development and Environmental Degradation in ASEAN-5. International Journal of Academic Research in Business and Social Sciences, 8(12), 14-32.

Copyright: (C) 2018 The Author(s)

Published by Human Resource Management Academic Research Society (www.hrmars.com)

This article is published under the Creative Commons Attribution (CC BY 4.0) license. Anyone may reproduce, distribute, translate and create derivative works of this article (for both commercial and non-commercial purposes), subject to full attribution to the original publication and authors. The full terms of this license may be seen

at: http://creativecommons.org/licences/by/4.0/legalcode

Vol. 8, No. 12, 2018, Pg. 14 - 32

http://hrmars.com/index.php/pages/detail/IJARBSS

JOURNAL HOMEPAGE

Full Terms \& Conditions of access and use can be found at http://hrmars.com/index.php/pages/detail/publication-ethics 


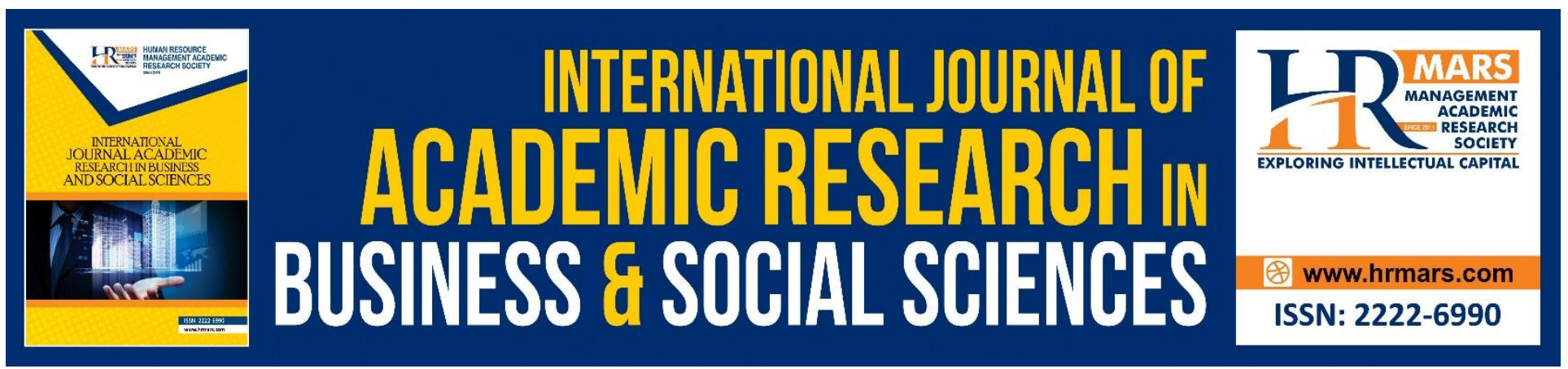

\title{
Financial Development and Environmental Degradation in ASEAN-5
}

\author{
Rosita Hamdan, Rossazana Ab-Rahim \& Sang Sook Fah \\ Faculty of Economics and Business, Universiti Malaysia Sarawak, 94300 Kota Samarahan, Sarawak, \\ Malaysia
}

\begin{abstract}
This study investigates the relationship between financial development and environmental degradation in ASEAN-5 countries namely Indonesia, Malaysia, Philippines, Singapore, and Thailand over the period of 2000 to 2014. The Panel Unit Root test, Panel Cointegration test, Vector Error Correction Model (VECM) Granger Causality, and Fully Modified Ordinary Least Square (FMOLS) are used in this study to examine the short-run and the long-run as well as the causality relationship among the variables. Variables employed in this study are carbon dioxide $\left(\mathrm{CO}_{2}\right)$ emissions, foreign direct investment (FDI), private domestic credit (DC), and market capitalization (MC). The empirical findings show that all the variables are stationary at order I(1) and there is a cointegration relationship among the variables. The results show that there is a bidirectional causality relationship between the $\mathrm{CO}_{2}$ and $\mathrm{FDI}$. Meanwhile, there is a unidirectional causality running from $\mathrm{CO}_{2}$ to $\mathrm{DC}, \mathrm{MC}$ to $\mathrm{FDI}$, and $M C$ to $D C$ respectively. The strong policy and institution structures are suggested to improve environmental degradation through new technologies and financial development and financial reforms play a role in protecting the environment.
\end{abstract}

Keywords: Financial Development, Environmental Degradation, ASEAN

\section{INTRODUCTION}

Financial development is considered as one of the important factors in respect to the relationship between economic growth and the environment. On the one hand, financial development mitigates the environmental problems by redirecting the financial resources such as foreign direct investment (FDI) and higher investment may speed up economic growth and hence affects the dynamic of the environmental performance (Tamazian et al., 2009). It also helps to preserve the environment and produce environment-friendly products which can help to reduce the environmental issue and prevent the environment from serious hurt by human activities. On the other hand, financial development such as stock traded and industry value added leads to the increase of the energy consumption; as a result, the emission of carbon dioxide $\left(\mathrm{CO}_{2}\right)$ increase and eventually leads to environmental degradation. Based on these two different viewpoints, the nexus of financial 
INTERNATIONAL JOURNAL OF ACADEMIC RESEARCH IN BUSINESS AND SOCIAL SCIENCES Vol. 8, No. 12, Dec, 2018, E-ISSN: 2222-6990 @ 2018 HRMARS

development on environmental performance is ambiguous. Hence, the question arises: does financial development lead to environmental degradation or vice versa?

Environmental degradation refers to the deterioration of the environment through the depletion of resources, the destruction of ecosystems and the extinction of wildlife (Trimurthyvishal, 2010) as well as reducing biological diversity and the general health of the environment (Mary, 2015). Environmental degradation is triggered by the human activities in the field of socioeconomic, institutional and technological variations and has become a serious problem; both developed and developing countries have faced many environmental problems such as deforestation, land degradation, water shortage and contamination, air pollution and the loss of biodiversity (World Bank, 2012). $\mathrm{CO}_{2}$ emission which mainly comes from fossil fuel consumption, such as coal, oil and gas is one of the main sources of the greenhouse effect and has captured great attention in the recent years.

Air pollution is one of the tragedies that faced by the Association of Southeast Asian Nations (ASEAN) countries in the past few decades. Since the 1980s, the haze problem (air pollution) has continuously dominated the agenda of ASEAN member-states as one of their top priorities in addressing environmental issues in Southeast Asia. In many cases, the land and forest fires mainly come from Indonesia's Riau Province, where lands are usually cleared for palm oil plantation (Yohanes et al., 2015) using a slash-and-burn technique (Peh, 2014). Pearl (2014) adds the climate change during the dry seasons and the El-Nino could trigger the land and forest fires. Greenpeace Asia Tenggara (2015) analysis showed that $40 \%$ of fire hotspots across Indonesia have been in peatlands ${ }^{1}$ which make up a fraction of the nation's landmass in the year 2015 . The primary source of haze in the region in Southeast Asia is the fires associated with deforestation, especially of peat forest. In the year of 2014 alone, $75 \%$ of fire alerts in Sumatra come from peatlands. The Greenpeace ${ }^{2}$ has analyzed that fires in Indonesia released globally significant concentration of greenhouse gasses (GHG). It is due to the peatlands soils that store a massive amount of carbon, $\mathrm{CO}_{2}$ emissions will be released through the cleared and drained of the peatlands for plantations. Hence, Indonesia's annual forest and peat fires are a man-made crisis, with devastating health impacts for Indonesia and its Southeast Asian neighbors as well as the global climate (Pearl, 2014).

It is ironic how human depends on the environment to satisfy their basic needs, human exploits the natural resources and human also dampens the environmental degradation. Economic activities like manufacturing, transport, consumption and disposal transform the status of natural resources, imposing continuous stress to the environment which leads to environmental damages. Georgescu-Roegen (1971) and Daly (1977) as well as recent study, Tariq \& Ab Rahim (2016) argue higher economic growth leads to higher production and consumption activities to satisfy human wants, thus causing more waste, more pollution and more pressure on environmental resources. On

\footnotetext{
${ }^{1}$ Peatland refers to an extensive tract of land where peat has formed.

${ }^{2}$ Greenpeace refers to an organization devoted to environmental activism, founded in the the United States and Canada in 1971.Greenpeace has employed passive resistance in opposition to commercial whaling, the dumping of toxic waste into the sea, and nuclear testing.
} 
this note, financial sector plays an essential role in deploying savings and allocating funds to productive endeavors (Shahbaz, 2013); financial development takes place when financial instruments, markets, and intermediaries work hand in hand to reduce the cost of information, enforcement, and transaction. Besides, it also plays an important role in economic development as developed financial markets can help to attract FDI and stimulate the economic growth (Frankel \& Romer, 1999). Hence, financial development may be another source that affects the environmental performance either in good or worse performance rather than only depends on its income level alone (Zhang, 2010).

There are two views regarding the effects of financial development on $\mathrm{CO}_{2}$ emissions. Some studies found a positive relationship between financial development and $\mathrm{CO}_{2}$ emissions. Shahbaz et al. (2010) and Chang (2014) claimed that a good financial development makes it possible to offer credits for environmentally friendly projects. As a result, FDI may lead to technological innovation by local firms and organizations which can help reduce energy use and emissions of $\mathrm{CO}_{2}$ (Alfaro, 2004; Alfaro et al., 2006; Bailliu, 2000; Hermes \& Lensink, 2003). Islam et al. (2013) claimed that there is a negative relationship between financial development and environmental degradation. On contrary to the first view, growing in financial intermediation can support increased lending to households and firms to purchase more items that included automobile and machinery, thereby increase the consumption of energy and emissions of $\mathrm{CO}_{2}$ increase indirectly (Chang, 2014). Thus, financial development can serve as an incentive for increased energy substitution (reduces emissions of $\mathrm{CO}_{2}$ ) while at the same time lending capital to the energy industry which increases energy consumption (triggers emissions of $\mathrm{CO}_{2}$ ). In other words, financial development correlates with FDI, industry value added in the percentage of gross domestic product (GDP) and domestic credit provided by the financial sector in the percentage of GDP which also influences environmental.

The remainder of the chapter is organized as follows: next section provides an overview of the financial development and environmental quality in ASEAN-5 countries follows by Past Studies section which presents a review of past studies on the relationship between financial development and environmental degradation. Subsequent section presents the data and description of variables as well as the methodology employs in this study. The last two sections offer the empirical findings and the discussion of the results of this study; follows by conclusion of this study.

\section{BACKGROUND OF ASEAN-5 COUNTRIES}

Financial Development

The aim of ASEAN Economic Community (AEC) is to create an economic union with the intent of facilitating trade, strengthening political ties and increasing financial harmonization across the region (Organization of Economic Countries Development (OECD), 2013); as well as the transformation of ASEAN into a region with free movement of goods, services, investment, skilled labor, and freer flow of capital (Asian Development Bank (ADB), 2013). Thus, it is important to fully realize the benefits of economic integration as there is a need to narrow the development gap between member countries through the transformation of ASEAN countries. As a result, the Initiative for ASEAN Integration (IAI) that seeks to promote financial and economic development is proposed. 
INTERNATIONAL JOURNAL OF ACADEMIC RESEARCH IN BUSINESS AND SOCIAL SCIENCES Vol. 8, No. 12, Dec, 2018, E-ISSN: 2222-6990 @ 2018 HRMARS

According to a report entitled "Southeast Asian Economic Outlook 2013" (OECD, 2013), ASEAN has to face the challenges of narrowing the social gap and the economic development gap between countries as it works towards its end goal of an AEC. ASEAN members are different with each other due to the different level of development, political system, investment environment, and economic structure. OECD further suggests that the narrowing development gaps indicator (NDGI) can be used to narrow the development differences and disparities in ASEAN from the more developing group of countries such as Indonesia, Philippines, Singapore, Malaysia, and Thailand with the less developing member countries of Cambodia, Lao PDR, Myanmar, and Viet Nam (CLMV). Hence, it would be interesting to investigate whether the financial development in ASEAN-5 countries (Indonesia, Malaysia, Philippines, Singapore, and Thailand) leads to environment degradation or vice versa. The diversity of the economy in ASEAN countries has been reflected through some of the standard metrics of financial development such as deposit money of bank assets, stock market capitalization, and the value of bonds outstanding as a proportion of GDP. The considerable differences in financial development indicators across ASEAN countries are largely associated with differences in the size of stock and bond markets, which is one of the financial development components (ADB, 2013).

World Economic Forum (2012) has reported that Singapore is ranked at the 4th place out of 62 countries with respect to the most advanced end of the development spectrum in economic growth. Singapore's foreign exchange, derivatives and equity markets are regarded as some of the most advanced in the world. Glass (2013) adds that highly developed financial markets in Singapore are complemented by a favorable legal and regulatory framework, as well as efficient and effective contract enforcement mechanisms. According to World Economic Forum (2012), Malaysia and Thailand, which are ranked at the 18th and 34th place respectively, are relatively robust in their financial intermediation capabilities, in particular, the size and depth of their equity and debt capital markets. In addition, the Philippines and Indonesia have comparatively immature financial systems which are ranked at 49th and 52nd respectively in globally. Indonesia and the Philippines are quite underdeveloped in retail access to financial services, and have smaller and inefficient of banking sectors as compared with another country. These countries will face the hardship in developing their capital accounts and domestic financial sector liberalization as they look to further developing the financial systems within the country (Glass, 2013).

Further development and regional integration of financial markets help to better capture the benefits from capital inflows and reduce the risks they can put forward to domestic economic stability. Emerging countries have made considerable progress since the global crisis in strengthening the financial soundness and governance of their banking systems (OECD, 2013). Besides, deeper capital markets dampen the volatility arising from fluctuation in foreign and the domestic investors' demands for domestic equities and fixed income instruments. The individual member states of ASEAN would be better able to minimize the adverse impact of external shocks on the economy; and this can be achieved if and only if they are to develop broad and liquid domestic financial markets as well as to improve their efficiency and stability before embarking in financial market integration (ADB, 2013). 
INTERNATIONAL JOURNAL OF ACADEMIC RESEARCH IN BUSINESS AND SOCIAL SCIENCES Vol. 8, No. 12, Dec, 2018, E-ISSN: 2222-6990 @ 2018 HRMARS

\section{Environmental Degradation}

In the context of ASEAN countries, deforestation has been five times the global average and ten times the average for the rest of Asia; Indonesia alone is deforested at a rate of 14 million hectares per year, with only 53 million hectares of total forest area left, and the deforestation caused the forest fires and peatland degradation. As a result, the country become the third-largest global GHG emitter, after China and the United States. Uncontrolled logging throughout Southeast Asia has contributed to several environmental degradations such as soil erosion, a collapse in agricultural productivity, increasing of pollution, the emergence of new tropical diseases, higher rural poverty problems, and massive species extinction and if the environmental performance is moving negatively, Southeast Asian forests could lose 13 to 42 percent (\%) of all of their species by the end of the century, half of which are likely to represent global species extinctions (Sovacool, 2009).

The GHG emission has resulted in global warming and climate change and as $\mathrm{CO}_{2}$ emissions play the main important anthropogenic of GHG, it has significantly contributed to the increase in global temperatures and climate change (Intergovernmental Panel on Climate Change, 2006). The main part of the increase in $\mathrm{CO}_{2}$ emissions is attributed to energy consumption, especially, fossil fuels burning such as oil, gas, and coal as well as for the usage of transportation, which release gasses such as $\mathrm{CO}_{2}$ and nitrogen oxide (Saboori \& Sulaiman, 2013).

Table 1: $\mathrm{CO}_{2}$ Emission in ASEAN-5 (metric tons, $\mathrm{M}$ )

\begin{tabular}{lccccc}
\hline Year & Indonesia & Malaysia & Philippines & Singapore & Thailand \\
\hline 2000 & 263.42 & 125.73 & 73.31 & 49.01 & 49.01 \\
2001 & 294.91 & 135.62 & 71.05 & 49.54 & 49.54 \\
2002 & 306.74 & 133.74 & 71.34 & 47.23 & 47.23 \\
2003 & 316.79 & 158.26 & 71.53 & 31.13 & 31.13 \\
2004 & 337.64 & 163.83 & 74.07 & 28.47 & 28.47 \\
2005 & 341.99 & 174.49 & 74.83 & 30.36 & 30.36 \\
2006 & 345.12 & 167.70 & 67.69 & 30.80 & 30.80 \\
2007 & 375.54 & 184.82 & 72.17 & 19.93 & 19.93 \\
2008 & 416.56 & 204.03 & 78.86 & 36.13 & 36.13 \\
2009 & 446.41 & 198.80 & 77.57 & 37.02 & 37.02 \\
2010 & 428.76 & 218.48 & 84.92 & 43.95 & 43.95 \\
2011 & 573.38 & 220.41 & 85.58 & 38.33 & 38.33 \\
2012 & 599.54 & 218.71 & 91.32 & 54.63 & 54.63 \\
2013 & 479.36 & 236.51 & 98.24 & 50.56 & 50.56 \\
2014 & 498.79 & 237.75 & 89.88 & 54.81 & 54.81 \\
2015 & 515.24 & 246.28 & 91.82 & 55.07 & 55.07 \\
\hline
\end{tabular}

Source: World Bank (2015)

Table 1 shows the increasing trend of $\mathrm{CO}_{2}$ emission in metric tons of ASEAN-5 countries from the year 2000 to the year 2015. Indonesia records the highest emission of $\mathrm{CO}_{2}$ throughout the year 
INTERNATIONAL JOURNAL OF ACADEMIC RESEARCH IN BUSINESS AND SOCIAL SCIENCES

Vol. 8, No. 12, Dec, 2018, E-ISSN: 2222-6990 @ 2018 HRMARS

due to the forest fires activities; while Thailand is the second highest emission of $\mathrm{CO}_{2}$ follow by Malaysia and Singapore in the third and fourth rank respectively. Philippines emits the lowest $\mathrm{CO}_{2}$ emission.

\section{LITERATURE REVIEW}

The relationship between financial development and environmental degradation has developed based on the framework of environmental Kuznets curve (EKC), established by Kuznets (1955). Kuznets suggests two ways to illustrate the relationship between economic development (income per capital) and environmental quality; namely the monotonic and non-monotonic shape of EKC. The empirical estimations suggest that as the economy develops, natural environmental quality initially declines, before showing an improvement (Mohapatra \& Giri, 2008). Earlier studies have analysed the theoretical issues on an inverted U-shaped EKC (Beckerman, 1972, 1992; and Simon, 1977, 1981). The hypothesis of the relationship between financial development and environmental degradation reveals that financial development is linked with environmental degradation initially and, the problem of environmental degradation tends to decrease as financial development achieves turning point of threshold levels of economic growth. Frankel and Romer (1999) claim financial liberalization and development may speed up economic growth and hence affect the dynamic of the environmental performance. The authors add that financial development provides developing countries with the motive to use new technology with clean and environmentally friendly production. On contrast, World Bank (1992) asserts although financial development may enhance economic growth, it may result in more industrial pollution and environmental degradation.

A bulk of past studies offers inconclusive evidence of the nexus between financial development and environmental degradation with respect to developed and developing countries. Studies such as Al-Mulali and Sab (2012), Leitao (2013), Shahbaz, Tiwari, and Nasir (2013), Bento (2014), and Gokmenoglu, Ozataz, and Eren (2015) show energy consumption and $\mathrm{CO}_{2}$ emission have a positive short-run and long-run causal relationship between financial development and economic development respectively. The results also reveal that energy consumption has a positive correlation with $\mathrm{CO}_{2}$ emission in the short-run and long-run. Shahbaz, Tiwari, and Nasir (2013), and Tamazian and Rao (2010) suggest the financial development can be used as an instrument to lower the energy emission to keep the environment free from degradation. However, financial liberalization is found to be harmful towards environmental quality if it is not accomplished in a strong institutional framework (Shahbaz, Tiwari, and Nasir, 2013). All the above-mentioned studies focus on the developed countries. In the context of developing countries, Tamazian, Chousa, and Vadlamannati (2009), Shahbaz, Islam, and Butt (2011), Shahbaz (2013), Salahuddin, Gow, and Ozturk (2015) show economic growth decreases the environmental degradation while financial development has a negative relationship with $\mathrm{CO}_{2}$ emissions in the long-run; financial development provides an incentive to firms to adopt the environment friendly techniques during production process (Shahbaz, 2013).

On contrast, Sehrawat, Giri, and Mohapatra (2015) claim financial development appears to increase environmental degradation. This is supported by Zhang (2010) and Javid and Sharif (2013) that financial intermediation scale proves an important driver for $\mathrm{CO}_{2}$ emissions increase as there is 
a close relationship among financial intermediation scale economic growth and $\mathrm{CO}_{2}$ emission. Next, a stream of past studies on the nexus between financial development and environmental degradation in ASEAN offer inconclusive evidence. Some studies show foreign direct investment, energy consumption and economic growth hamper the environmental performance of ASEAN countries (Lean \& Smyth, 2010; Hitam \& Borhan, 2012; Shahbaz, Hye, Tiwari, \& Leitao, 2013); Chandran and Tang (2013) suggest economic growth and $\mathrm{CO}_{2}$ emissions are interrelated in ASEAN-5 countries. As far as this study is concerned, there are no studies has focused on the nexus between financial development and environmental degradation of ASEAN countries. Another stream of studies has tended to confine their analysis on individual countries; for instance, Islam, Shahbaz and Alam (2011) and Islam, Shahbaz, Ahmed, and Alam (2013) claim financial development has a negative relationship with energy consumption in Malaysia. Shahbaz, Solarin, and Mahmood (2012) add that high financial development and trade reduces $\mathrm{CO}_{2}$ emissions, while high energy consumption and economic growth increase $\mathrm{CO}_{2}$ emissions.

\section{METHODOLOGY}

This study investigates the nexus between financial development and environmental degradation in ASEAN-5 countries over the study period of 2000-2014. The variables employed as a measure of financial development is private domestic credit (DC) which includes all credit to many sectors on a gross basis with the net exception of credit to the central government, it can be used to represent the financial development in a certain country (World Bank, 2015) as it consists of monetary authorities, deposit money banks and other financial corporations (Al-Mulai \& Sab, 2012; Alam et al., 2014; Shahzad et al. 2014). Next, foreign direct investment (FDI) is the sum of equity capital, reinvestment earnings, and other capital, referring to direct investment equity flows of the economy in a country from a foreign country (World Bank, 2015). FDI has a direct relationship with financial development as well FDI leads to the economic growth of a country (Shahbaz et al., 2011; Tamazian \& Rao, 2010; Hitam \& Borhan, 2012). Market capitalization (MC) is also known as market value refers to the share price multiple with the number of shares outstanding as the market capitalization listed companies does not include investment companies, mutual funds, or other collective investment vehicles (Zhang, 2010; Shahbaz et al., 2011).

Next, $\mathrm{CO}_{2}$ emission is used as the indicator for the environmental degradation since $\mathrm{CO}_{2}$ emissions is a harmless by-product of combustion and becoming the primary GHG responsible for the problem of global warming (Intergovernmental Panel on Climate Change, 2007). Regulating and monitoring man-made emissions of $\mathrm{CO}_{2}$ from various economic activities has become a concerned issue of global warming at international level (Cline, 1992; Revkin, 2000). It is expected that the higher the emission of $\mathrm{CO}_{2}$, the higher the environmental degradation is, $\mathrm{CO}_{2}$ is measured in metric tons. Moreover, the scope of the dimension impact makes $\mathrm{CO}_{2}$ pollution more suitable for country-level aggregate study (Tamazian, Chousa, \& Vadlamannati, 2009) as compared to the energy consumption which has included others sources such as fossil fuel consumption and coal consumption. 
INTERNATIONAL JOURNAL OF ACADEMIC RESEARCH IN BUSINESS AND SOCIAL SCIENCES

Vol. 8, No. 12, Dec, 2018, E-ISSN: 2222-6990 @ 2018 HRMARS

Table 2: Description of Variables

\begin{tabular}{lccc}
\hline & Descriptive data & Source & Expected Sign \\
\hline Dependent Variable & $\mathrm{CO}_{2}$ in metric tons & WDI & \\
Independent Variables & FDI in \% of GDP & WDI & + \\
& DC in \% of GDP & WDI & + \\
& MC in \% of GDP & WDI & + \\
\hline
\end{tabular}

Note: $\mathrm{CO}_{2}=$ carbon dioxide emissions; $\mathrm{FDI}$ = foreign direct investments; $\mathrm{DC}$ = private domestic capital; and $\mathrm{MC}=$ stock market capitalization.

Source: World Development Indicator (various years)

The description of variables used in this study is shown in Table 2. The financial development variables, namely FDI is expected to have a positive relationship with the environmental degradation; an increase in FDI will enhance the economic growth, whereby various industry activities will lead to increase in environment degradation. Next, another indicator of financial development, DC includes all credit to many sectors on a gross basis; thus, the higher the DC, the higher the financial development as well as the higher the environmental degradation. Last but not least, the MC indicator which involves the multiplication of the share price and the number of share outstanding; hence, an increase in $\mathrm{MC}$ leads to increase in financial development and environmental degradation also increases. With this respect, FDI is measured as the ratio of net inflows to GDP, MC of listed companies is measured in percentage of GDP, and DC that provided by the financial sector is measured in term of percentage of GDP.

The dependent variable is transformed to logarithms form while other variables are in linear form in the panel model form. The log-linear model is used in this analysis, it is due to the impact of independent variables on the dependent variable is hypothesized to be increasing at an increasing rate; besides, the log-linear model is applied in this investigation whereby dependent variable adjusts in percentage form to a unit of change in independent variables (Gujarati \& Porter, 2009). A panel model of environmental degradation is established due to it is more reliable with stable parameter estimates, panel model has the advantages in controlling the serial correlation and reduces individual heterogeneity (Al-Mulali, Tang, \& Ozturk, 2015). The methodology such as Panel Unit Root Test to investigate the characteristic of stationary for all series, Panel Cointegration Test, Panel Vector Error Correction Model (VECM) Granger Causality Test, and Panel Fully Modified Ordinary Least Square (FMOLS) are conducted to examine the relationship between the series in term of a long run and short run as explained in section. The panel model that represents the environmental degradation is shown below:

$$
\mathrm{CO}_{2 \mathrm{it}}=f\left(\mathrm{FDI}_{\mathrm{it}}+\mathrm{DC}_{\mathrm{it}}+\mathrm{MC}_{\mathrm{it}}\right)
$$

where,

$\mathrm{CO}_{2}=$ Carbon Dioxide Emission 
$\mathrm{FDI}=$ Foreign Direct Investment

DC = Domestic Credit

MC = Market Capitalization

The dependent variable is presented in its natural log while other independent variables are presented in a normal form where provided the log-linear panel model form, with a view of testing the validity of the EKC hypothesis. Besides, the error term or known as the random error is added to the model. Hence, the model can be written as follows:

$$
L \mathrm{CO}_{2 \mathrm{it}}=B_{1 i} \mathrm{FDl}_{\mathrm{it}}+B_{3 i} \mathrm{MC}_{\mathrm{it}}+b_{4 i} \mathrm{DC} \mathrm{C}_{\mathrm{it}}+€_{\mathrm{it}}
$$

The $B_{1 i}, b_{2 i}, b_{3 i}, b_{4 i}$, and $B_{5 i}$ represent the slope of coefficients, where $i$ represent a cross section ( $1 \ldots 5$ ASEAN-5 countries), it represents the time period for the year 2000 to the year 2014 , and $€$ represent the error term in this model.

\section{RESULTS}

Descriptive Statistics

Based on Table 3, variable that has the highest mean and highest maximum value is MC with 100.6307 and 299.6 respectively. It then follows by $\mathrm{DC}, \mathrm{FDI}$, and $\mathrm{LCO}_{2}$ respectively. Moreover, $\mathrm{DC}$ has the highest median and highest minimum value among other variables. MC also has the highest standard deviation with 71.9150, DC with 39.3516, FDI with 6.6785, and $\mathrm{LCO}_{2}$ with 0.6258 respectively. Meanwhile, the statistics of Jarque-Bera test state that all the series are normally distributed with zero mean and finite variance. As FDI has the highest value of Jarque-Bera that is 56.8097 following by the variables of $\mathrm{MC}$ and $\mathrm{DC}$ while the lowest rank is $\mathrm{LCO}_{2}$. All variables have 75 of observation throughout this study.

Table 3: Descriptive Statistics of the Variables

\begin{tabular}{|c|c|c|c|c|}
\hline & $\mathrm{LCO}_{2}$ & FDI & DC & MC \\
\hline Mean & 5.2173 & 5.3413 & 88.0080 & 100.6307 \\
\hline Median & 5.3058 & 2.8000 & 79.3000 & 78.8000 \\
\hline Maximum & 6.2601 & 26.5000 & 168.5000 & 299.6000 \\
\hline Minimum & 3.1950 & 0.1000 & 34.2000 & 16.9000 \\
\hline $\begin{array}{l}\text { Standard } \\
\text { Deviation }\end{array}$ & 0.6258 & 6.6785 & 39.3516 & 71.9150 \\
\hline Jarque-Bera & 4.3821 & 56.8098 & 6.9843 & 12.7510 \\
\hline Observation & 75 & 75 & 75 & 75 \\
\hline
\end{tabular}

\section{Empirical Results}

The result presented in Table 4 reveal that the variable of $\mathrm{LCO}_{2}$ is not significant in Fisher-PP in level form while the variable of DC in Fisher-ADF and Fisher-PP are not significant in level form as the statistics unable to reject the null hypothesis of a panel unit root and the variables are non-stationary. 
INTERNATIONAL JOURNAL OF ACADEMIC RESEARCH IN BUSINESS AND SOCIAL SCIENCES Vol. 8, No. 12, Dec, 2018, E-ISSN: 2222-6990 C 2018 HRMARS

However, all of the variables are significant at the first difference. The null hypothesis of a unit root can be rejected and thus all the variables are stationary at the first differences, indicating that they are integrated at order one, i.e., I (1).

Table 4: Panel Unit Root Test Results

\begin{tabular}{|c|c|c|c|c|}
\hline & \multicolumn{2}{|c|}{ Level } & \multicolumn{2}{|c|}{ First Difference } \\
\hline Variables & Intercept & $\begin{array}{c}\text { Intercept And } \\
\text { Trend }\end{array}$ & Intercept & $\begin{array}{c}\text { Intercept And } \\
\text { Trend }\end{array}$ \\
\hline \multicolumn{5}{|c|}{ Panel I : Fisher-ADF } \\
\hline & $27.6768 * *$ & $24.9337 * *$ & $64.5914^{* *}$ & $51.9141 * *$ \\
\hline & $40.8060 * *$ & $37.4134 * *$ & $66.4058 * *$ & $54.7750 * *$ \\
\hline & 8.70885 & 1.51466 & $29.3284 * *$ & $40.3169 * *$ \\
\hline & $21.8417^{* *}$ & $28.8497 * *$ & $62.7411^{* *}$ & $46.3882 * *$ \\
\hline \multicolumn{5}{|c|}{ Panel II : Fisher-PP } \\
\hline & 12.6500 & 15.6484 & $71.2501^{* *}$ & $65.3215^{* *}$ \\
\hline & $41.2219 * *$ & $55.8218 * *$ & $104.575^{* *}$ & $80.2181 * *$ \\
\hline & 7.7912 & 2.02432 & $29.7993 * *$ & $76.2171 * *$ \\
\hline & $28.2034 * *$ & $55.1331 * *$ & $114.502 * *$ & $93.6446 * *$ \\
\hline
\end{tabular}

Note: The lag length is selected automatically using the Schwarz Information Criteria (SIC).

** Significance at $5 \%$ level

After all the variables are in stationary form, the test can proceed to cointegration test by using Pedroni cointegration test as the test requires all the variables should be in stationary form at the first difference. The null hypothesis is that the variables are not cointegrated while the alternative hypothesis is that the variables are cointegrated. The result from Pedroni cointegration test is presented in Table 5. The results show that the eight statistics are significant at $5 \%$ level such as the panel v-Statistic, Panel PP-Statistic, Panel ADF-Statistic, Panel v-Statistic (Weighted Statistic), Panel PP-Statistic (Weighted Statistic), Panel ADF-Statistic (Weighted Statistic), Group PP-Statistic, and Group ADF-Statistic. Hence, the null hypothesis of no cointegration can be rejected; it can be concluded that there is a long-run relationship between the variables in this study. 
INTERNATIONAL JOURNAL OF ACADEMIC RESEARCH IN BUSINESS AND SOCIAL SCIENCES

Vol. 8, No. 12, Dec, 2018, E-ISSN: 2222-6990 @ 2018 HRMARS

Table 5: Result of Panel Cointegration Test Results

\begin{tabular}{l|c}
\hline Test Statistics & Statistics \\
\hline Panel V-Statistic & $2.397739^{* *}$ \\
Panel Rho-Statistic & -1.247615 \\
Panel PP-Statistic & $-10.99247^{* *}$ \\
Panel ADF-Statistic & $-11.62691^{* *}$ \\
Panel V-Statistic (Weighted Statistic) & $6.007081^{* *}$ \\
Panel Rho-Statistic (Weighted Statistic) & -0.131124 \\
Panel PP-Statistic (Weighted Statistic) & $-5.143766^{* *}$ \\
Panel ADF-Statistic (Weighted Statistic) & $-5.124489^{* *}$ \\
Group Rho-Statistic & 1.231129 \\
Group PP-Statistic & $-4.894197^{* *}$ \\
Group ADF-Statistic & $-4.647607^{* *}$
\end{tabular}

Note: $* *$ Significance at $5 \%$ level

Table 6: Panel Granger Causality Test Results

\begin{tabular}{l|cccccc}
\hline & $\begin{array}{l}\text { Short Run } \\
\end{array}$ & & & & & Long Run \\
& F- Statistics & & & & & T-Statistics \\
\hline & & $\Delta \mathrm{LCO}_{2}$ & $\Delta \mathrm{FDI}$ & $\Delta \mathrm{DC}$ & $\Delta \mathrm{MC}$ & $\mathrm{ECT}(-1)$ \\
\hline $\begin{array}{l}\text { Dependent } \\
\text { Variables }\end{array}$ & $\Delta \mathrm{LCO}_{2}$ & - & $4.959^{* *}$ & 0.238 & 0.825 & $2.140^{* *}$ \\
& & & & & & \\
& $\Delta \mathrm{FDI}$ & $2.554^{* *}$ & - & 0.003 & $4.741^{* *}$ & 0.876 \\
& $\Delta \mathrm{DC}$ & $4.529^{* *}$ & 2.388 & - & $4.681^{* *}$ & $2.356^{* *}$ \\
& $\Delta \mathrm{MC}$ & 1.091 & 0.977 & 0.076 & - & 0.283 \\
\hline
\end{tabular}

Note: ECT $(-1)$ represented the error correction term lagged one period. $\Delta$ represented the first difference.

\section{** Significance at $5 \%$ level}

Since the variables are cointegrated, the Granger causality test based on the VECM is utilised and the result is given in Table 6 . The null hypothesis of this test is that there is no causality exists between the variable while the alternative hypothesis is that there is causality exist between the variable. The results show some of the variables are statistically significant at $5 \%$ level of short-run causality where the null hypothesis can be rejected. Hence, in the short run causality reveals that there is a bidirectional causality running between $\mathrm{LCO}_{2}$ and $\mathrm{FDI}$. Moreover, there is unidirectional causality from $\mathrm{MC}$ to $\mathrm{FDI}$, from $\mathrm{LCO}_{2}$ to $\mathrm{DC}$, and from $\mathrm{MC}$ to $\mathrm{DC}$. Besides, there is also long run causality exist between the variable where $\mathrm{LCO}_{2}$ and $\mathrm{DC}$ have a bidirectional long run relationship. Generally, the Granger causality test results show feedback causality between all the variables in both short run and long run. 


\section{DISCUSSION}

The Pedroni cointegration test confirms a cointegrating relationship among the variables. Panel VECM Granger Causality test is employed to estimate the both long-run and short-run relationship among the variables where there is a bidirectional causality running between $\mathrm{LCO}_{2}$ and FDI as it has the similar result in the study by Shahbaz, Rehman, Hurr, and Zakaria (2014) and Pao and Tsai (2010), Shahbaz, Solarin, and Ahmood (2012). Besides, there is also a unidirectional running from $\mathrm{LCO}_{2}$ to DC, MC to FDI as support in the study of Shahbaz, Islam, and Butt (2011), and MC to DC respectively. The presence of long-run cointegration between the variables also is confirmed. FMOLS approach is also employed to test the robustness of the existence of a long-run relationship among the variables in this study. Overall, the results show that financial development does play a role for environmental performance as well as it validates the contribution of the financial sector to improve the quality of the environment (Shahbaz, Hye, \& Tiwari, 2013).

The results of this study show that financial development granger-causes $\mathrm{CO}_{2}$ emissions reveals that adoption of energy conservation would not adversely affect economic growth. As financial sector has to fix its focus on the allocation of funds to those firms which adopt environmentfriendly technologies and encourage the firms to use more energy efficient technology for production purpose and to save the environment from degradation. This result is supported by Tamazian and Rao (2010) and Shahbaz, Hye, and Tiwari (2013). The result also reveals that MC only has a short run relationship where it is critical to improving the functioning of financial markets for boosting longterm economic growth. Thus, the integration of banks and capital markets may be a reasonable direction for a promising financial system so as to promote a low-carbon development (Zhang, 2011). Besides, the capital market is also affected by various factors such as domestic political situation and economic factors as well as become a driver of economic growth and carbon emissions. This could be due to the easy access of the enterprises towards the external finance by providing bank loans or other actions to enhance investment scale.

The empirical result reveals that MC granger causes DC as it might due to the banking sector that can be used to represent market capitalization access to domestic credit of financial sector that is linked to the environmental quality. This result is similar to the study by Shahbaz, Tiwari, and Nasir (2013). This implies that increase in the ratio of domestic credit makes it easier for the consumers and investors in emerging market and developing economic to borrow funds from the financial sector, thus stimulating the energy demand which brings effect towards the carbon dioxide emissions (Chang, 2015). The causality results in this study also indicated that there is exists of bidirectional causality between FDI and emissions and unidirectional causality running from MC to FDI, MC to DC, as well as $\mathrm{LCO}_{2}$ to DC. This evidence seems to support the pollution haven and the both halo and scale effect as used in the by Pao and Tsai (2011). Hence, ASEAN-5 should examine the qualifications for foreign investment in order to attract FDI inflows as well as to promote environmental protection through the technological transfer with other countries to avoid the damage on the environment. In this study, the results of VECM indicate that there is a long-run relationship between the financial development and environmental degradation as supported by Boutabba (2013). Hence, the efforts 
INTERNATIONAL JOURNAL OF ACADEMIC RESEARCH IN BUSINESS AND SOCIAL SCIENCES

Vol. 8, No. 12, Dec, 2018, E-ISSN: 2222-6990 @ 2018 HRMARS

to overcome the environmental degradation require considerable attention to the carbon emission through financial development.

\section{CONCLUSION}

Generally, Fisher-ADF and Fisher PP panel unit root test shows that all the estimated variables become stationary after first differences or integrated of the first order, I(1) at $5 \%$ level of significance; hence, the panel Pedroni test is performed and the results show the variables are cointegrated. DC is found to have a positive significant impact on $\mathrm{CO}_{2}$ emissions in the long-run through VECM and FMOLS test. The Granger causality results suggest a bidirectional causality running between $\mathrm{LCO}_{2}$ and $\mathrm{FDI}$ and a unidirectional relationship from $\mathrm{LCO}_{2}$ to $\mathrm{DC}$, from $\mathrm{MC}$ to $\mathrm{FDI}$ and $\mathrm{MC}$ to DC. In other words, this study demonstrates that financial development contributes towards carbon dioxide emissions in ASEAN-5 countries.

Based on the findings of this study, it is suggested that government of ASEAN-5 play their roles to improve environmental degradation by establishing strong policy and institution structures as suggested by Tamazian and Rao (2010) that have long-term benefits for reductions in carbon dioxide emissions. It is due to financial development has a significant relationship with environmental degradation. Thus, the government of ASEAN-5 should support the development of new technologies that lead to a less carbon-intensive economy and green growth through sharing their individual experience on sustainable development practices. For example, promoting the use of green technology in a vehicle such as more energy efficient vehicles or hybrid vehicles as well as being selective in FDI strategies to control the pollution industries to relocate themselves. This action might reduce $\mathrm{CO}_{2}$ emissions in these countries.

In addition, as the financial development plays a significant role in the quality of the environment as it has reveals the long-run relationship with environmental degradation. Thus, financial institutions can approach the challenges of environment degradation with direct and indirect methods. For example, the financial system of each country can involve indirect method through the investment in research and development (R \& D) on innovative technologies relating to cleaner energy such as biomass, solar and solid waste. Moreover, introducing financial reforms by the government can be used as an instrument to keep the environment clean. In this regards, the government of each country helps the market to establish a strong policy and framework. For example, development of efficient capital market can be a useful policy option. It is due to the firms can reduce the liquidity risk and can mobilize the required funds through portfolio diversification that is greatly useful in developing sound technology in the long-run particularly.

Furthermore, the financial regulatory bodies of each ASEAN-5 countries should consider practical ways to help channel the financial development into a sustainable system which is environmental friendly. Thus, this study recommends that the ASEAN-5 countries need to significantly boost investment in order to help protect the environment. For instance, financial intermediaries can offer special loans with a low discount if the investment is made based on the low carbon based products. In this way, businesses, as well as individual, can shift to a more renewable 
energy items. As argued by Ang and Liu (2006), the need for further empirical analysis remains pertinent and hopefully, this study will facilitate improved further investigation. Overall, there is still much work to do concerning the influence of financial development and $\mathrm{CO}_{2}$ emission in ASEAN-5 such as the comparison of influencing mechanism of financial development on carbon dioxide emissions among different countries, different interactions between financial development and $\mathrm{CO}_{2}$ emission among ASEAN-5 with some other developed or developing countries.

Acknowledgement: This work was supported by Ministry of Higher Education and Universiti Malaysia Sarawak [grant numbers RAGS/e(9)/908/2012(09)].

\section{REFERENCES}

Alfaro. L., Chanda. A., Kalemli-Ozcan. S., \& Sayek, S. (2006). How does foreign direct investment promote economic growth: Exploring the effects of financial markets on linkages? Working Paper No. 07-013. Harvard Business School.

Alfaro. L., Chanda. A., Kalemli-Ozcan. S., \& Sayek. S. (2004). FDI and economic growth: The role of local financial markets. Journal of International Economics 64, 113-134.

Al-Mulali. U. \& Ozturk. I. (2015). The effect of energy consumption, urbanization, trade openness, industrial output, and the political stability on the environmental degradation in the MENA (The Middle East and North African) region. Energy, 84, 382-389.

Al-Mulali. U. \& Sab. C. N. B. C. (2012). The impact of energy consumption and $\mathrm{CO}_{2}$ emission on the economic and financial development in 19 selected countries. Renewable and Sustainable Energy Reviews, 16, 4365-4369.

Al-Mulali. U., Tang. C. F, \& Ozturk. I. (2015). Estimating the Environment Kuznets Curve hypothesis: Evidence from Latin America and the Caribbean countries. Renewable and Sustainable Energy Reviews, 50, 918-924.

Ang, B.W. \& Liu, N., (2006). A cross-country analysis of aggregate energy and carbon intensities. Energy Policy, 34 (15), 2398-2404.

Asian Development Bank, ADB (2013). The Road to ASEAN Financial Integration: A Combined Study on Assessing the Financial Landscape and Formulation Milestones for Monetary and Financial Integration in ASEAN. Philippines.

Bailliu. J. N. (2000). Private capital flows, financial development, and economic growth in developing countries. Working Paper No. 00-15. Bank of Canada.

Beckerman. W. B. (1992). Economic growth and the environment: Whose growth? Whose environment? World Development, 20 (4), 481-96.

Borensztein, E., De Gregorio, J., \& Lee, J. W. (1998). How does foreign direct investment affect economic growth? Journal of international Economics, 45(1), 115-135.

Borhan. M., Ahmed. E. M., \& Hitam. M. (2012). The impact of $\mathrm{CO}_{2}$ on economic growth in ASEAN 8. Procedia - Social and Behavioral Sciences 35, $389-397$.

Boutabba (2013). The impact of financial development, income, energy and trade on carbon emissions: Evidence from the Indian economy. Retrieved from www.univ-evry.fr/EPEE 
INTERNATIONAL JOURNAL OF ACADEMIC RESEARCH IN BUSINESS AND SOCIAL SCIENCES

Vol. 8, No. 12, Dec, 2018, E-ISSN: 2222-6990 C 2018 HRMARS

Chandran. V. G. R. \& Tang. C. F. (2013). The impacts of transport energy consumption, foreign direct investment, and income on $\mathrm{CO}_{2}$ emissions in ASEAN-5 economies. Renewable and Sustainable Energy Reviews, 24, Pp.445-453.

Chang. S. C. (2014). Effects of financial development and income on energy consumption. International Review of Economics and Finance, 35, 28- 44.

Chen. S. T., Kuo. H-I., \& Chen. C-C. (2007). The relationship between GDP and electricity consumption in 10 Asian countries. Energy Policy, 35, 2611-2621.

Click \& Plummer (2003). Stock market integration in ASEAN after the financial crisis. Working Paper Series Vol. 2003-06. The International Centre for the Study of East Asian Development, Kitakyushu.

Cline. W. (1992). The Economics of Global Warming. Institute for International Economics. Washington: DC.

Daly. H. E. (1977). Steady-State Economics. The Economics of Biophysical Equilibrium and Moral Growth. W.H. Freemann and Company: San Francisco.

Frankel. J. \& Romer. D. (1999). Does trade cause growth? American Economic Review, 89 (3), 379 399.

Georgescu-Roegen. N. (1971). The Entropy Law and the Economic Process. Harvard University Press. Cambridge: MA.

Glass (2013). ASEAN's Financial Gap. Retrieved from https://agenda.weforum.org/2013/06/aseansfinancial-development-gap.

Greenpeace Asia Tenggara. (2015). Greenpeace Briefer on the 2015 Forest and Peatlands Fire \& Smoke Haze. Retrieved from http://www.wri.org/blog/2014/04/preventing-forest-firesindonesia-focus-riauprovince-peatland-and-illegal-burning.

Gujarati. D. N. \& Porter. D. C. (2009). Basic Econometric. $5^{\text {th }}$ Ed. McGraw- Hill/ Irwin. New York: NY. Americas.

H. (2014). El Nino, Indonesian Peatland Conversion Add Up to Haze Risk. Retrieved from www.thejakartaglobe.com:http://thejakartaglobe.beritasatu.com/news/el-nino-indonesianpeatland-conversion-add-haze-risk.

Hermes. N., \& Lensink. R. (2003). Foreign direct investment, financial development and economic growth. Journal of Development Studies, 40, 142-163.

Hitam. M. B. \& Borhan. H. B. (2012). FDI, growth, and the environment: Impact on quality of life in Malaysia. Procedia - Social and Behavioral Sciences 50, Pp.333-342.

Intergovernmental Panel on Climate Change (IPCC). (2006). Climate Change Synthesis Report 2006. Retrieved from /http://www.ipcc.ch/S.

Islam. F., Shahbaz, M., \& Alam. M. (2011). Financial development and energy consumption nexus in Malaysia: A multivariate time series analysis. MPRA Paper No. 28403. Retrieved from http://mpra.ub.uni-muenchen.de/28403.

Islam. F., Shahbaz. M., Ahmed. A. U., \& Alam. M. M. (2013). Financial development and energy consumption nexus in Malaysia: A multivariate time series analysis. Economic Modelling, 30, 435-441.

Javid. M. \& Sharif. G. F. (2013). Energy Consumption, Financial development and $\mathrm{CO}_{2}$ emissions in Pakistan. MPRA Paper No. 48287. Retrieved from http://mpra.ub.uni-muenchen.de/48287. 
INTERNATIONAL JOURNAL OF ACADEMIC RESEARCH IN BUSINESS AND SOCIAL SCIENCES Vol. 8, No. 12, Dec, 2018, E-ISSN: 2222-6990 @ 2018 HRMARS

Koh. K. L. \& Robinson. N. A. (2002). Regional Environmental Governance: Examining the Association of Southeast Asian Nations (ASEAN) Model. In Global Environmental Governance Options \& Opportunities. By Daniel C. Esty and Maria H. Ivanova, editors Yale Center for Environmental Law \& Policy. Retrieved from http://environment.yale.edu/publicationseries/documents/downloads/h-n/koh.pdf.

Kuznets. S. (1955). Economic growth and income inequality. American Economic Review, 45 (1), 1-28. Lean. H. H. \& Smyth. R. (2010). CO2 emissions, electricity consumption and output in ASEAN. Applied Energy, 87, Pp. 1858-1864.

Leitao. N. C. (2013). The environmental Kuznets curve and globalization: The empirical evidence for Portugal, Spain, Greece, and Ireland. Energy Economics Letters, 1(1), Pp.15-23.

Mary. M. (2015). What is environmental degradation? Retrieved from http://www.wisegeek.com/what-is-environmental-degradation.htm.

Mohapatra. G. \& Giri. A. K. (2008). Economic development and environmental quality: An econometric study in India. Management of environmental quality: An International Journal, 20(2), Pp. 175-191.

OECD (2013). Southeast Asian Economic Outlook 2013: With Perspectives on China and India, Paris: OECD Publishing.

Pao. H. T. \& Tsai. C. M. (2010). Multivariate granger causality between $\mathrm{CO}_{2}$ emissions, energy consumption, FDI (foreign direct investment) and GDP (gross domestic product): Evidence from a panel of BRIC (Brazil, Russian Federation, India, and China) countries. Energy, 36, 685-693.

Pedroni. P. (1999). Critical values for cointegration tests in heterogeneous panels with multiple regressors. Oxford Bulletin of Economics and Statistics, 61, 653-670.

Pedroni. P. (2004) Panel cointegration: asymptotic and finite sample properties of pooled time series tests with an application to the PPP hypothesis. Econometric Theory, 20, 597-625.

Peh. D. L.-H. (2014). South-East Asia forest fires: Blazing the policy trail. Oryx, 1-6.

Revkin. A. (2000). A plunge in the use of food stamps causes concern. New York Times.

Saboori. B. \& Sulaiman. J. (2013). $\mathrm{CO}_{2}$ emissions, energy consumption and economic growth in Association of Southeast Asian Nations (ASEAN) countries: A cointegration approach. Energy, $55,813-822$.

Shahbaz (2012). Multivariate granger causality between $\mathrm{CO}_{2}$ emissions, energy intensity, financial development and economic growth: evidence from Portugal. MPRA Paper No. 3777. Retrieved from http://mpra.ub.uni-muenchen.de/37774.

Shahbaz M., Samia. N., \& Talat. A. (2011). Environmental consequences of economic growth and foreign direct investment: evidence from panel data analysis. MPRA Paper No. 32547. Retrieved from http://mpra.ub.uni-muenchen.de/32547.

Shahbaz, M., Islam, F., \& Butt, M. S. (2011). Financial development, energy consumption and $\mathrm{CO}_{2}$ emissions: Evidence from ARDL approach for Pakistan. MPRA Paper No. 30138, Retrieved from http://mpra.ub.uni-muenchen.de/30138.

Shahbaz. M. (2013). Does financial instability increase environmental degradation? Fresh evidence from Pakistan. Economic Modeling, 33, 537-544. 
INTERNATIONAL JOURNAL OF ACADEMIC RESEARCH IN BUSINESS AND SOCIAL SCIENCES Vol. 8, No. 12, Dec, 2018, E-ISSN: 2222-6990 @ 2018 HRMARS

Shahbaz. M., Hye, Q. M. A., Tiwari. A. K., \& Leitao. N.C. (2012). Economic growth, energy consumption, financial development, international trade and $\mathrm{CO}_{2}$ emissions in Indonesia. Renewable and Sustainable Energy Reviews, 25, 109-121.

Shahbaz. M., Hye. Q. M. A., \& Tiwari. A. K. (2013). Economic growth, energy consumption, financial development, international trade and $\mathrm{CO}_{2}$ emissions, in Indonesia. MPRA Paper No. 43722. Retrieved from http://mpra.ub.uni-muenchen.de/43722.

Shahbaz. M., Islam. F., \& Islam. M. M. (2010). The impact of financial development on energy consumption in Pakistan: Evidence from ARDL bounds testing approach to cointegration. Proceedings of the Second International Conference on the Role of Social Sciences and Humanities in Engineering 2010, 12-14 November 2010. Penang, Malaysia: Bayview Beach Resort.

Shahbaz. M., Khan.S, Iqbal.T.M (2012). The dynamic link between energy consumption, economic growth, financial development and trade in China: Fresh evidence from multivariate framework analysis. MPRA Paper No. 42974. Retrieved from http://mpra.ub.uni;-muenchen.de/42974.

Shahbaz. M., Solarin. S. A., \& Mahmood. H. (2012). Does financial development reduce CO2 emissions in Malaysian economy? A time series analysis. MPRA Paper No. 40603. Retrieved from https://mpra.ub.uni-muenchen.de/40603.

Shahbaz. M., Tiwari. A. K., \& Nasir. M. (2013) The effects of financial development, economic growth, coal consumption and trade openness on environment performance in South Africa. Retrieved from http://www.researchgate.net/publication/254443091.

Simon. J. J. (1977). The Economics of Population Growth. Princeton, NJ: Princeton University Press.

Simon. J. J. (1981). The Ultimate Resource. Princeton, NJ: Princeton University Press.

Beckerman. W. B. (1972), Economic Development and the Environment: A False Dilemma. Reprinted as Beckerman, W.B (1995). Growth, the Environment and the Distribution of Incomes: Essays by a Skeptical Optimist. Cheltenham: Edward Elgar.

Sovacool. B. J. (2009). Reassessing energy Security and the trans-ASEAN natural gas pipeline network in Southeast Asia. Pacific Affairs, 82(3), 467- 486.

Tamazian. A. \& Rao. B. B. (2010). Do economic, financial and institutional developments matter for environmental degradation? Evidence from transitional economies. Energy Economics, 32, 137-145.

Tamazian. A., Chousa. J. P., \& Vadlamannati. K. C. (2009). Does higher economic and financial development lead to environmental degradation: from BRIC countries. Energy Policy, 37, 246253.

Tariq, B., \& Ab Rahim, R. (2016). The environmental effects of intra-industry trade in the SAARC region. International Journal of Business and Society, 17(1), 113-130.

Trimurthyvishal (2010). Environmental degradation. Retrieved from http://www.studymode.com/essays/Environmental-Degradation- 507423.html.

World Bank (2015). Overview. Retrieved from

http://www.worldbank.org/en/country/malaysia/overview.

World Bank (2015). Overview. Retrieved from

http://www.worldbank.org/en/country/singapore/overview.

World Bank (2015). Overview. Retrieved from 
http://www.worldbank.org/en/country/thailand/overview.

World Bank. (1992). World Development Report 1992: Development and the Environment. New York: Oxford University Press. World Bank. Retrieved from https://openknowledge.worldbank.org/handle/10986/5975 License: CC BY 3.0 IGO.

World Economic Forum (2012). The Financial Development Report 2012. World Economic Forum USA Inc. New York, USA.

Yohanes. S.P., Astriana. F., \& Adiwena.W. (2015). Ensuring the ASEAN Agreement of Transboundary Haze's (AATHP) Effectiveness: A Case Study of Riau Province's Haze Summary. The Habibie Center - ASEAN Studies Program 2(4), 1-2.

Zhang. Y. J. (2010). The impact of financial development on carbon emissions: An empirical analysis in China. Energy Policy, 39, 2197-2203. 